\title{
MANAGEMENT OF RADIATION SAFETY BY OPTIMIZING THE PARAMETERS OF PROTECTIVE STRUCTURES
}

\author{
O.V. Mamontov, B.O. Malyk, O.V. Tokarieva \\ Kharkiv National University of Radio Electronics, \\ Kharkiv, Ukraine \\ E-mail: olena.tokarieva@nure.ua
}

The task of radiation safety management by the optimization of protective structures parameters has been considered. The techniques for calculating the attenuation coefficient of radiation of multilayer floor slabs, the range of constructional materials and the method of the optimization calculation of multilayer protective structures have been analyzed. The analysis has shown that the achievement of the maximum possible efficiency of protection at random distribution of materials is improbable. The optimization task has been solved of the distribution of materials on protective structures and their constructional elements and the list of target functions and restrictions has been made. The algorithm and the program have been developed, the method of optimization calculation of a group of protective structures for the purpose of increasing personnel radiation safety has been improved, and the calculation data testifying the efficiency of the offered approach have been obtained.

\section{INTRODUCTION}

The risks of accidents, disasters, terrorist attacks and the use of nuclear weapons are still present in the world. Industrial, social, political and military emergencies are the causes of excessive radioactive exposure affecting the population and the personnel of facilities.

The most cost-effective means of collective protection in areas with low population density and nonnumerical personnel are simple protective structures and shelters. The effectiveness of protection against ionizing radiation, including gamma radiation, largely depends on the tightness and absorption capacity of the slab constructions and enclosing surfaces.

In the event of an increased risk of an emergency situation, the building of protective structures is usually carried out at an accelerated pace. It can be carried out individually and in a group manner. The group method in which a group of protective structures are built using common resources (budgetfunds and constructional materials) is of particular interest. In both cases the task of the efficient use of available resources arises.

The existing methodology for calculating the gamma-radiation attenuation coefficient of multilayer enclosures and slabs takes into account a set of conditions. They include: the number of layers, the thickness of each layer and the half-value thickness. However, this method does not allow achieving the maximum protective effect with limited resources (of budget funds and constructional materials).

The relevance of the work is dictated by the need to develop the most effective radiation exposure protection of people under the conditions of limited resources.

The objective of this work is to optimize the group of protective structures, aimed at improving the antiradiation protection of people meaning to the optimum choice of materials and their distribution over constructive elements of the protective structure. At the same time, the target function accepts the maximum value, and the restrictions are respected.

\section{OPTIMIZATION OF CALCULATING THE PARAMETERS OF A GROUP OF PROTECTIVE STRUCTURES}

For the best distribution of material resources and achievement the maximum protective effect, the task of optimization for the chosen quality criterion (target function) and fulfillment of restriction conditions is solved.

The works $[1,2]$ are concerned with the study of hybrid polymer composite materials for electromagnetic screening. Despite the effective suppression of electromagnetic interference and radio frequency range radiation, these materials are not effective against gamma-radiation protection. In the work [3], a protective concrete structure is developed and the required thickness of the slabs with improved shielding properties at the permissible dose of irradiation of personnel is calculated. This material is more effective for protection against radiation. However, the reduction of radiation exposure due to a combination of used materials was not considered.

The paper [4] deals with the characteristics of multilayer composite slabs to protect people and electronics from radiation in space. The data on using some materials as fillers are presented. The improvement of protective properties due to the properties of materials is achieved, but the optimization task of maximum protection against radiation was not solved. The paper [5] shows the optimized design of the multilayer screen for protection against radiation. However, the task of minimizing radiation exposure by combining the materials used was not considered here either. The paper [6] is devoted to the determination of dependence of exposure dose on the dimensions and materials of buildings. That research does not solve the problem of the group optimization of anti-radiation enclosures.

The problem of group optimization of enclosures based on the Monte Carlo random search method was solved in the papers $[7,8]$. The method includes a free choice of structures, calculation methods and prepared materials, as well as their distribution over the 
partitions. After that the restrictions are checked. A persistent improvement is achieved due to the multiple stochastic process of calculating the result up to an acceptable value. The method assumes several variants of setting the optimization task, in which the enclosures are optimized in order to protect people from external influences. The task of increasing the radiation safety of people was not considered in these works.

Fig. 1 shows the simplest shelter model that underlies the calculation.

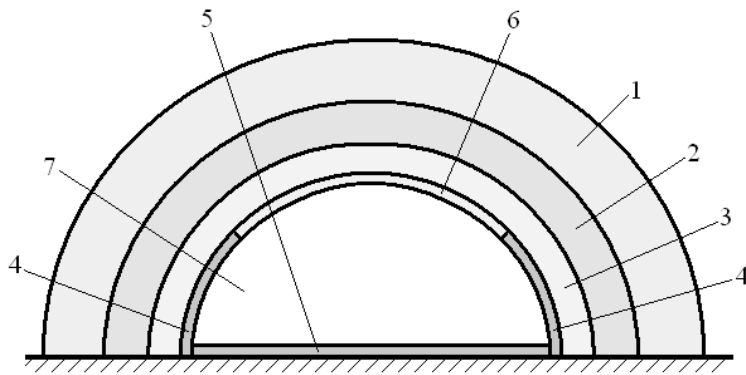

Fig. 1. Simplified model of protective structure (section): 1-3-layers of absorbing materials (3- bearing layer);4-6-layers of facing materials; 7 - protected space

To solve this problem, the following initial data set is proposed:

- the desired gamma-reduction coefficient;

- the target function depending on the option selected;

- the list of restrictions;

- the list of available materials for each constructional element (see Fig. 1);

- the list and the amount of available materials;

- the number and the capacity of protective structures;

- the unit cost and half-value thickness of gamma radiation attenuation for each prepared material.

The following options for the target function are available:

- the average gamma-attenuation coefficient;

- the total cost of the protective structures;

- the "safety/cost" ratio.

When selecting a target function, one should be guided by the relevance of the optimization task under the specific conditions. The average gamma-radiation attenuation coefficient characterizes the degree of the collective protection. This indicator is recommended for accelerated building activity with the known results of the forecast of the radiation situation.

The average gamma attenuation coefficient is calculated from the formula:

$$
F_{1}=\bar{K}=\frac{\sum_{i=1}^{m} P_{i} n_{i}}{\frac{\sum_{i=1}^{m} P_{i} n_{i}}{K_{i}}} \rightarrow \min ,
$$

where $\bar{K}$ - the average gamma-radiation attenuation coefficient; $i$ and $m$ - respectively, the number of the protective structure and the required quantity of protective structures; $P_{i}$ - dose rate of gamma-radiation outside the shelter (result of the forecast of radiation situation), R/hr; $n_{i}$ - individual protective structure capacity; $K_{i}$-gamma-radiation attenuation coefficient;

$$
K_{i}=2^{\left(D_{1} / d_{1}+D_{2} / d_{2}+D_{3} / d_{3}\right)}
$$

$D_{1}-D_{3}-$ thickness $(\mathrm{cm})$ of the absorbing layer 1,2 , and 3 , respectively (see Fig. 1 ); $d_{1}-d_{3}-$ thickness (cm) of the half-reduction layer 1, 2, and 3, respectively.

The total cost of a group of protective structures is an estimate that includes the cost of the materials, fasteners and work. This target function is recommended for pre-construction activity and an acute shortage of financial resources:

$$
F_{2}=S=\sum_{i=1}^{m} \sum_{j=1}^{l_{i}} V_{j} C_{j} \rightarrow \min ,
$$

where $S$ - cost, c.u.; $j$ and $l_{j}$ - respectively, the number and quantity of typical constructional elements in a building; $V_{j}$ and $C_{j}$ - respectively, the amount $\left(\mathrm{m}^{3}\right)$ and the cost of the material (c.u.) including fastening elements and work.

The safety/cost ratio is a composite indicator. It can be used when none of the previous indicators can be given any priority:

$$
F_{3}=\frac{\bar{K}}{S}=\frac{\sum_{i=1}^{m} P_{i} n_{i}}{\frac{\sum_{i=1}^{m} P_{i} n_{i}}{K_{i}} \cdot \sum_{i=1}^{m} \sum_{j=1}^{l_{i}} V_{j} C_{j}} \rightarrow \max .
$$

The following restrictive criteria are proposed:

- minimum permissible value of gamma-radiation attenuation coefficient of a single structure unit $K_{M I N}$;

- maximum permissible total cost of protective structures $S_{M A X}$, c.u.;

- number of built structures $m_{N B S}^{*}$.

The value of gamma-radiation attenuation coefficient for an individual protective structure is estimated by the inequality:

$$
K_{j} \geq K_{M I N} .
$$

The cost of the protective structures is estimated by means of the inequality:

$$
S \leq S_{M A X} .
$$

The quantity of the built structures is estimated by the expression:

$$
m^{*}=m_{N B S}^{*} \cdot
$$

If necessary, the restrictions can be imposed on weight, mechanical strength and capacity of people. 


\section{IMPROVEMENT OF THE METHOD \\ AND THE ALGORITHM \\ OF OPTIMIZATION CALCULATION \\ OF A GROUP OF PROTECTIVE STRUCTURES}

This optimization task is based on discrete sets, which include the lists of protective structures, constructional elements and prepared materials. The target functions and restrictions are generally nonlinear. Therefore the problem can be solved by the methods of nonlinear discrete programming.

In this paper, the Monte Carlo random search method has been used, similarly to $[7,8]$. The calculation algorithm is shown in Fig. 2. It uses the stochastic process of random distribution of prepared materials among the protective covers and structural elements. The multiple calculation of the target function and verification of restrictions allow choosing the best result.

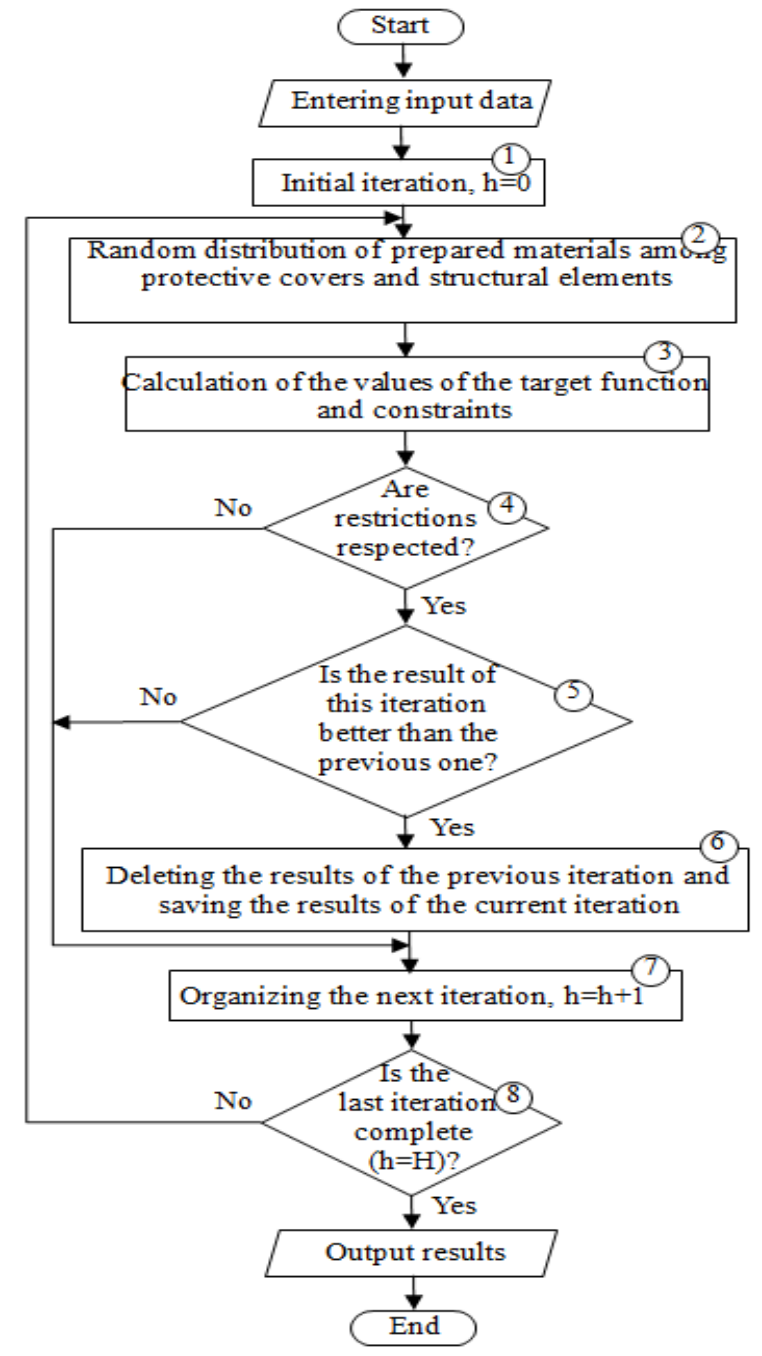

Fig. 2. Diagram of the algorithm for calculating a group of protective structures

The advantage of the method and the algorithm consists in blocks $2-4$. In contrast to works [7, 8], the prepared materials are distributed over different protective structures and separate constructional elements. The use of the target functions (1), (3), and
(4), as well as restrictions (5)-(7) makes it possible to increase the radiation safety of people.

\section{CONFIRMATION OF A SIGNIFICANT EFFECT IN ACHIEVING THE OPTIMUM SOLUTION}

To confirm the effect, a computer program has been developed and a verification calculation of four simplest protective structures has been performed (see the model in Fig. 1). According to the predetermined conditions, the protective structures were located in the area with the same level of radiation. The floor dimensions of each structure were $5 \times 2.5 \mathrm{~m}$ and the height was $2.5 \mathrm{~m}$. They housed 15 people. The minimum permissible gamma radiation attenuation coefficient was 70 . The allowed materials for building the shelters are given in Table 1 . The characteristics of the materials are given in Table 2.

Table 1

Numbers of available materials under the statement of the problem

\begin{tabular}{|c|c|c|c|c|c|}
\hline \multicolumn{5}{|c|}{ Number of the typical structural element in Fig. 1} \\
\hline$j 1$ & $j 2$ & $j 3$ & $j 4$ & $j 5$ & $j 6$ \\
\hline $1-3$ & $1-3$ & $4-7$ & $8-10$ & $8-10$ & $8-10$ \\
\hline
\end{tabular}

The target function (1) was chosen, as well as restrictions (5) and (7). Fig. 3 represent the data of the stochastic calculation process (see respectively, block 2 and block 3 of the algorithm, Fig. 2).

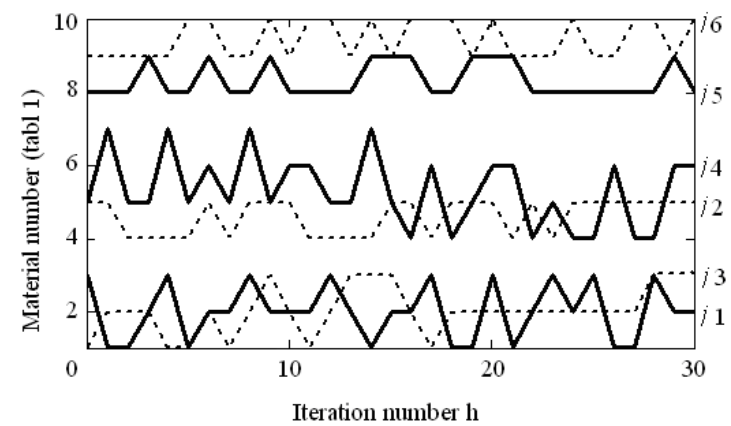

a

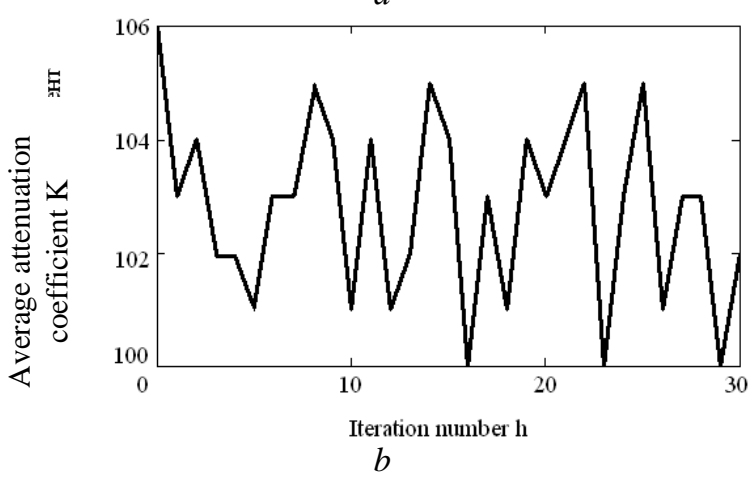

Fig. 3. Data of the stochastic calculation process depending on the iteration number:

$a$-distribution of the prepared materials over the constructive elements of structures;

$b$-random values of the mean gamma-radiation attenuation coefficient of the group of protective structures 
Table 2

Material characteristics

\begin{tabular}{|c|c|c|c|c|c|}
\hline $\begin{array}{l}\text { Material } \\
\text { number }\end{array}$ & $\begin{array}{c}\text { Name of the } \\
\text { material } \\
\text { (construction) }\end{array}$ & Material purpose & $\begin{array}{c}\text { Thickness of } \\
\text { the layer, } \\
\mathrm{cm}\end{array}$ & $\begin{array}{c}\text { Half-value } \\
\text { thickness of } \\
\text { gamma-radiation } \\
d, \mathrm{~cm}\end{array}$ & $\begin{array}{c}\text { Available } \\
\text { amount of the } \\
\text { material }\end{array}$ \\
\hline 1 & $\begin{array}{l}\text { fine grade } \\
\text { material } 1\end{array}$ & \multirow{3}{*}{ radiation absorption } & 30 & 15 & $18 \mathrm{~m}^{3}$ \\
\hline 2 & $\begin{array}{l}\text { fine grade } \\
\text { material } 2\end{array}$ & & 70 & 18 & $6 \mathrm{~m}^{3}$ \\
\hline 3 & $\begin{array}{l}\text { fine grade } \\
\text { material } 3\end{array}$ & & 70 & 25 & not restricted \\
\hline 4 & $\begin{array}{c}\text { reinforced- } \\
\text { concrete } \\
\text { construction } 1\end{array}$ & \multirow{4}{*}{$\begin{array}{c}\text { radiation absorption, } \\
\text { bearing capability }\end{array}$} & 25 & 14 & $40 \mathrm{~m}^{3}$ \\
\hline 5 & $\begin{array}{c}\text { reinforced- } \\
\text { concrete } \\
\text { construction } 2\end{array}$ & & 30 & 15 & $40 \mathrm{~m}^{3}$ \\
\hline 6 & $\begin{array}{c}\text { reinforced- } \\
\text { concrete } \\
\text { construction } 3\end{array}$ & & 30 & 16 & $20 \mathrm{~m}^{3}$ \\
\hline 7 & $\begin{array}{c}\text { reinforced- } \\
\text { concrete } \\
\text { construction } 4\end{array}$ & & 35 & 17 & $20 \mathrm{~m}^{3}$ \\
\hline 8 & $\begin{array}{l}\text { surfacing } \\
\text { material } 1\end{array}$ & \multirow{3}{*}{$\begin{array}{l}\text { protection against } \\
\text { fragments of destruction } \\
\text { during physical impacts, } \\
\text { thermal insulation, } \\
\text { decorative properties }\end{array}$} & 2.5 & 30 & $35 \mathrm{~m}^{2}$ \\
\hline 9 & $\begin{array}{l}\text { surfacing } \\
\text { material } 2\end{array}$ & & 2.5 & 30 & $35 \mathrm{~m}^{2}$ \\
\hline 10 & $\begin{array}{l}\text { surfacing } \\
\text { material } 3\end{array}$ & & 1.5 & 40 & $40 \mathrm{~m}^{2}$ \\
\hline
\end{tabular}

Fig. 4 shows the polygons of random values distribution of the average gamma-radiation attenuation coefficient, which are obtained at different numbers of iterations.

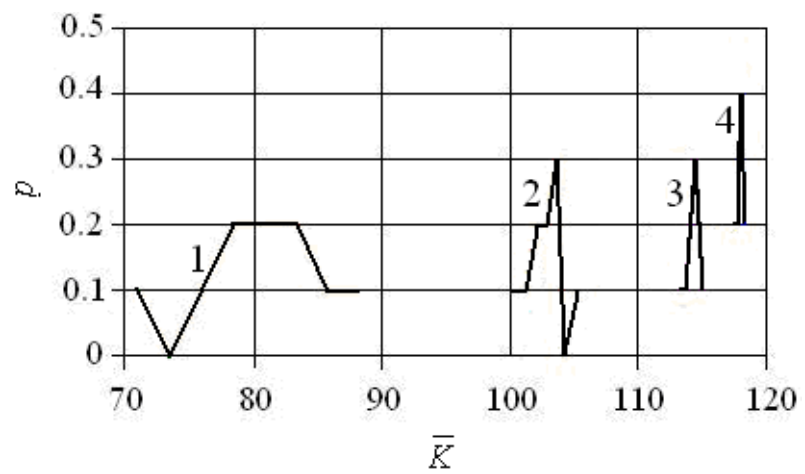

Fig. 4. Distribution polygons of the average gammaradiation attenuation coefficient: $p$ - probability; 1 -at the number of iterations $10^{3} ;$
2 - at the number of iterations $10^{4}$;
3 -at the number of iterations $10^{5}$;
4 -at the number of iterations $10^{6}$

Fig. 5 provides statistical data [9] that show a steady improvement in optimization results as the number of iterations increases.
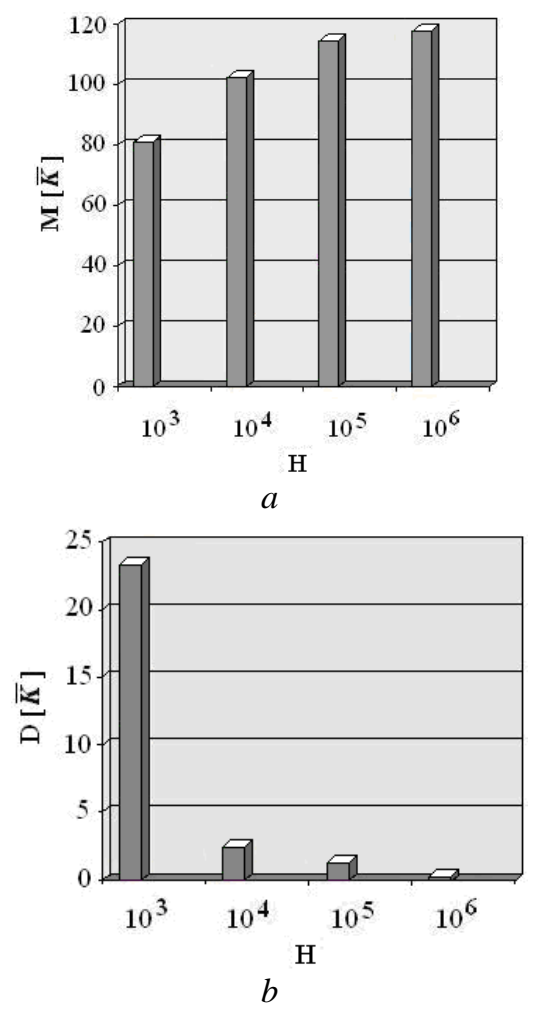

Fig. 5. Statistical data of optimization calculation results: $a$ and $b$-dependence diagrams of

mathematical expectation $M[\bar{K}]$ and dispersion $D[\bar{K}]$, respectively 
As it can be seen in Fig. 5, the best optimization result was obtained at the number of iterations $10^{6}$. The further increase in the number of iterations does not have a noticeable effect. Therefore, this result can be considered optimal. The optimal plan of materials distribution over the slabs is given in Table 3 .

The average gamma radiation attenuation coefficient for the structures was 119. The result of one-time random distribution of materials, corresponding to the minimum number of iterations, was 81 . Thus, as a result of the optimization this index has increased by 1.5 times. Thus, the effect of increasing radiation safety has been confirmed.

Table 3

Optimal material distribution plan (see Table 2) for protective covers

\begin{tabular}{|c|c|c|c|c|c|c|c|}
\hline \multirow{2}{*}{$\begin{array}{l}\text { Quantity } \\
\text { of } \\
\text { protective } \\
\text { covers }\end{array}$} & \multirow{2}{*}{$\begin{array}{c}\text { Gamma- } \\
\text { radiation } \\
\text { attenuation } \\
\text { coefficient }\end{array}$} & \multicolumn{6}{|c|}{$\begin{array}{l}\text { Number of the constructive } \\
\text { element, according to Fig. } 1\end{array}$} \\
\hline & & 1 & 2 & 3 & 4 & 5 & 6 \\
\hline 2 & 164 & 3 & 1 & 4 & 10 & 10 & 10 \\
\hline 1 & 137 & 3 & 2 & 5 & 8 & 8 & 10 \\
\hline 1 & 71 & 3 & 3 & 6 & 8 & 10 & 10 \\
\hline
\end{tabular}

The enhanced approach is characterized by the algorithmic simplicity, and can be used for operational building of a small number of simple protective structures (units). The increase in the number of structures and constructional elements requires an increase in the amount of calculations. This will require the use of more sophisticated optimization methods and computer programs.

\section{CONCLUSION}

The following tasks need to be completed in order to achieve the following objectives:

- the statement of the optimization task of calculating the group of protective structures has been carried out. The statement of the task includes the initial data, variants of target function, restrictions and recommendations on their use;

- the method and the algorithm of optimization calculation by introducing changes aimed at improving the radiation safety of people has been improved.

A significant effect when achieving an optimal solution has been confirmed by a calculated way. As a result of the optimization, the average reduction coefficient of gamma radiation of the group of protective structures has increased by 1.5 times. Accordingly, the total dose absorbed by humans under the conditions reviewed will also be reduced by 1.5 times.

\section{REFERENCES}

1. V. Bhingardive, K.G. Prasanna Kar, B. Suryasarathi. Lightweight, flexible and ultra-thin sandwich architectures for screening electromagnetic radiation // RSC Advances. 2016, N 6(74), p. 70018-70024.

2. R.B. Jagadeesh Chandra, B. Shivamurthy, S.D. Kulkarni, M.S. Kumar. Hybrid polymer composites for EMI shielding application - a review // Materials Research Express. 2019, N 8(6), p. 5212852134.

3. S. Debojit, B. Arnabs, R. Mizanur, M. Monish. Optimization of Radiation Shielding Concrete for Radiotherapy Treatment Room at Bangabandhu Sheikh Mujib Medical University // Key Engineering Materials. 2016, N 8, p. 338-344.

4. N.A. Galehdari, A.D. Kelkar. Characterization of Nanoparticle Enhanced Multifunctional Sandwich Composites Subjected to Space Radiation // ASME International Mechanical Engineering Congress and Exposition. 2017, February 8, 5 p.

5. Jeong Dong Kim, Sangjoon Ahn, Yong Deok Lee, Chang JePark. Design optimization of radiation shielding structure for lead slowing-down spectrometer system // Nuclear Engineering and Technology. 2015, N 3(47), p. 380-387.

6. Takuya Furuta, Fumiaki Takahashi. Study of radiation dose reduction of buildings of different sizes and materials // Journal of Nuclear Science and Technology. 2015, N 6(52), p. 897-904.

7. O. Mamontov, T. Stytsenko. Development of a method for optimization calculation of a group of sound-insulating panels for airborn noise protection // Eastern-European Jornal of Interprise Technologies. 2019, N 3/10(99), p. 32-37.

8. A. Bielikov, O. Mamontov, R. Papirnyk, T. Stytsenko, K. Ostapov, V. Shalomov, S. Ragimov, A. Melnichenko. Improvement of the method of calculating a group of sound-insulating panels // Eastern-European Jornal of Interprise Technologies. 2019, N 6/10(102), p. 55-60.

9. O.M. Rybalko. Vyshcha matematyka (spetsialni rozdily). Osnovy teorii imovirnostei z elementamy matematychnoi statystyky [Higher Mathematics (special sections). Fundamentals of Probability Theory with Elements of Mathematical Statistics]. Kharkiv: "Kolehium", 2014, p. 359 (in Ukrainian). 


\title{
УПРАВЛЕНИЕ РАДИАЦИОННОЙ БЕЗОПАСНОСТЬЮ ПУТЕМ ОПТИМИЗАЦИИ ПАРАМЕТРОВ ЗАЩИТНЫХ СООРУЖЕНИЙ
}

\author{
А.В. Мамонтов, Б.А. Малик, Е.В. Токарева
}

Рассмотрена задача управления радиационной безопасностью путем оптимизации параметров защитных сооружений. Проанализированы методики расчета коэффициента ослабления радиации многослойного перекрытия, ряд конструкционных материалов и метод оптимизационного расчета многослойных защитных конструкций. Показано, что достижение максимально возможной эффективности защиты от ионизирующего излучения, в том числе гамма-излучения, при случайном распределении материалов маловероятно. Решена задача оптимизации распределения материалов по сооружениям и их конструктивным элементам, рассмотрен перечень целевых функций и ограничений. Разработаны алгоритм и программа, усовершенствован метод оптимизационного расчета группы сооружений с целью повышения радиационной безопасности персонала, получены расчетные данные, свидетельствующие об эффективности предложенного подхода.

\section{УПРАВЛІННЯ РАДІАЦІЙНОЇ БЕЗПЕКОЮ ШЛЯХОМ ОПТИМІЗАЦІЇ ПАРАМЕТРІВ ЗАХИСНИХ СПОРУД}

\section{О.В. Мамонтов, Б.О. Малик, О.В. Токарєва}

Розглянуто задачу управління радіаційною безпекою шляхом оптимізації параметрів захисних споруд. Проаналізовано методики розрахунку коефіцієнта ослаблення радіації багатошарового перекриття, ряд конструкційних матеріалів і метод оптимізаційного розрахунку багатошарових захисних конструкцій. Показано, що досягнення максимально можливої ефективності захисту від іонізуючого випромінювання, в тому числі гамма-випромінювання, при випадковому розподілі матеріалів малоймовірно. Розв'язана задача оптимізації розподілу матеріалів по спорудах і їх конструктивних елементів, розглянуто перелік цільових функцій і обмежень. Розроблено алгоритм і програма, удосконалено метод оптимізаційного розрахунку групи споруд з метою підвищення радіаційної безпеки персоналу, отримані розрахункові дані, що свідчать про ефективність запропонованого підходу. 